\title{
PENGARUH KETEBALAN KAIN TERHADAP MOTIF BATIK PADA KAIN TENUN SUTRA SAMIA
}

\author{
THE EFFECT OF FABRIC THICKNESS ON BATIK MOTIFS \\ ON SAMIA SILK WOVEN FABRIC
}

\author{
Dana Kurnia Syabana, Novita Ekarini, Yudi Satria, Pandji Hardjanto \\ Balai Besar Kerajinan dan Batik, Jl. Kusumanegara No.7 Yogyakarta \\ E-mail: syabanadana@gmail.com
}

Tanggal diterima: 5 Agustus 2020, direvisi: 24 Oktober 2020, disetujui terbit: 6 November 2020

\begin{abstract}
ABSTRAK
Hasil akhir suatu produk batik dapat dipengaruhi oleh jenis kain dan kontruksinya. Salah satu jenis kain yang umum digunakan untuk produk batik adalah sutra. Sutra Samia dihasilkan dari ulat Samia cynthia ricini sutra yang memakan daun jarak atau daun singkong karet. Penelitian ini bertujuan untuk melihat pengaruh ketebalan kain sutra Samia terhadap motif batik yang dihasilkan. Metode kualitatif digunakan dengan mengukur interpretasi responden dengan skala Likert terhadap motif dan parameter malam batik. Kain sutra Samia diperlakukan dalam kondisi kering dan lembab dengan 1 kali dan 2 kali pencapan, pencelupan sebanyak 5 kali dengan pewarna alam tingi (Ceriops tagal) dan fiksasi kapur dan tunjung. Hasil yang didapatkan kain A dengan kondisi lembab 2 kali pencapan dan fiksasi tunjung (Ab2t) memiliki nilai kesempurnaan motif "sangat baik". Kain B kondisi lembab dengan 2 kali pencapan dan fiksasi tunjung $(\mathrm{Bb} 2 \mathrm{t})$ memiliki nilai ketegasan tapak klowong dan tapak isen "baik". Kain $\mathrm{C}$ kondisi kering dengan 2 kali pencapan dan fiksasi tunjung (Ca2t) memiliki nilai daya tembus "cukup baik", sedangkan kain A kondisi lembab dengan 2 kali pencapan dan fiksasi tunjung (Ab2t) memiliki nilai kerataan pelekatan malam batik "baik". Ketebalan kain, kondisi perlakuan awal, proses pencapan, serta fiksasi yang berbeda akan berpengaruh terhadap kesempurnaan motif, ketegasan tapak klowong, tapak isen, daya tembus, serta kerataan malam batik yang dihasilkan pada kain tenun sutra Samia.
\end{abstract}

Kata kunci: sutra samia, tebal kain, motif batik

\section{ABSTRACT}

The final result of a batik product can be influenced by fabric materials and its construction. One of the fabric materials commonly used for batik products is silk. Samia silk produced from Samia cynthia ricini silk caterpillars that feed on castrol or rubber cassava leafage. This research aims to see the effect of the thickness of Samia silk fabric on batik motif. Qualitative methods are used by measuring the interpretation of respondents with a Likert scale against motifs and batik waxes parameters. Samia silk fabric is treated in dry and humid conditions with 1 time and 2 times stamping processes, 5 times batik dyeing with natural dye tingi (Ceriops tagal) and fixation using lime and tunjung. The results obtained by fabric A processed in moist conditions, 2 times stamping, and with tunjung fixation (Ab2t) gives value of motif "excellent". Fabric B processed in moist condition, 2 times stamping, and with tunjung fixation (Bb2t) gives firmness of klowong tread and isen tread value "good". Fabric C processed in dry condition, 2 times stamping, and with tunjung fixation (Ca2t) gives translucent power value "quite good". While fabric A which processed in moist condition with 2 times stamping and tunjung fixation (Ab2t) has the flatness of batik wax value "good". The thickness of the fabric, the initial treatment conditions, the stamping process, and the different fixations used affected perfection of the pattern, firmness of the klowong and isen tread, permeability fabric towards batik wax, and the eveness of batik wax on the woven fabric of Samia silk.

Keywords: samia silk, thick fabric, batik motif

\section{PENDAHULUAN}

Kekayaan budaya Indonesia sangat beragam, salah satu diantaranya yaitu batik. Batik berasal dari kata "amba" yang berarti tulis dan kata "nitik" yang artinya titik dalam bahasa Jawa. ${ }^{1}$ Menurut Kusumastuti dan Syamwil, batik berasal dari kata "ambatik" yang berarti menulis titik. ${ }^{2}$ Definisi batik adalah kerajinan tangan sebagai hasil pewarnaan secara perintangan menggunakan malam (lilin batik) panas sebagai perintang warna dengan alat utama pelekat lilin batik berupa canting tulis dan atau canting cap untuk membentuk motif tertentu yang memiliki makna. ${ }^{3}$ Menurut McCabe, batik adalah proses pembuatan motif atau ornamen pada bahan tertentu, sebagian besar kain katun, dengan lilin panas sebagai perintang warna. ${ }^{4}$ Batik 
merupakan warisan budaya tak benda (intangible cultural heritage) yang telah diakui oleh UNESCO pada tanggal 2 Oktober 2009 dari Indonesia. . $^{1,5,6}$ Media batik yang umum digunakan yaitu kain mori, kain sutra. Sutra di dunia sebanyak $90 \%$ berasal dari Bombyx mori yang memakan daun murbei, dan sisanya sebesar $10 \%$ berasal dari ulat sutra bukan Bombyx mori. ${ }^{7}$ Terdapat beberapa jenis sutra yang bukan dihasilkan oleh ulat pemakan daun murbei, diantaranya yaitu sutra Eri, sutra Tasar, dan sutra Muga. ${ }^{8}$ Sutra Eri dihasilkan oleh 2 spesies ulat, yaitu Samia ricini dan Philosamia ricini atau disebut juga ulat sutra jarak (castor silkworm) karena memakan daun tanaman jarak. Syabana et al. telah melakukan penelitian pewarnaan alam batik pada kain sutra Samia dengan membandingkan hasil penyerapan warna terhadap perbedaan perlakuan mordan tunjung, tawas, dan kapur tohor. Hasil menunjukkan bahwa terdapat perbedaan intensitas ketuaan dan arah warna pada setiap perlakuan mordan. ${ }^{9}$

Pewarnaan menggunakan zat warna alam pada kain kain sutra telah dilakukan Lestari dan Satria menggunakan kulit kayu Angsana sebagai bahan pewarna alami, hasil penelitiannya disebutkan kulit kayu Angsana dapat digunakan sebagai pewarna alami pada kain sutra Bombyx dengan arah warna coklat, dan memiliki nilai ketahanan luntur terhadap pencucian dengan skala 4-5. ${ }^{10}$ Pada penelitian Murwati, mengenai teknologi proses batik kombinasi sasirangan yang menggunakan 3 jenis kain yang berbeda yaitu voalisima, primisima, dan sutra super T54 didapatkan proses batik sasirangan dipengaruhi oleh jenis kain, tebal kain, proses jahit-ikat, jenis benang pengikat, dan cara pewarnaan. ${ }^{11}$ Kain voalisima paling sesuai untuk kain batik sasirangan karena lebih tipis dibanding sutra dan primissima.

Penelitian dengan media pada batik yang berbeda juga dilakukan Apriliana \& Syamwil, menggunakan kain paris, kain mori, dan kain blacu. $^{7}$ Dalam penelitian tersebut, disebutkan bahwa perbedaan konstruksi kain dapat mempengaruhi kualitas batik terutama bauran warna dan gradasi. Selain kontruksi kain, parameter lain yaitu antihan dapat mempengaruhi pegangan tangan, penyerapan air, penampilan fisik, efek estetika, daya tembus udara, serta kilau. ${ }^{12}$ Menurut Mandegani et al., kualitas produk batik salah satunya dipengaruhi oleh jenis kain yang digunakan. ${ }^{13}$

Sejauh ini belum ada studi mengenai daya tembus malam dan motif batik pada kain tenun sutra Samia. Oleh karenanya, permasalahan yang diajukan dalam studi ini yaitu bagaimanakah daya tembus malam dan motif yang dihasilkan pada kain tenun sutra Samia? Selain itu, penelitian ini juga bertujuan untuk mengetahui pengaruh ketebalan kain sutra Samia terhadap daya tembus malam batik dan juga motif batik yang dihasilkan.

\section{METODE}

Penelitian dilakukan di Balai Besar Kerajinan dan Batik dalam kegiatan in house riset pada tahun 2019, dengan judul " Eksplorasi Batik Pada Kain Tenun Sutra Samia Untuk Produk Fesyen". Metode yang digunakan pada penelitian ini yakni eksperimen proses pembatikan dan pewarnaan kain sutra Samia pada berbagai variasi, yakni ketebalan kain, kondisi kain, dan juga jumlah proses pencapan malam batik. Hal ini dilakukan untuk menganalisis lebih lanjut pengaruh tebal kain terhadap daya tembus malam batik pada kain tenun sutra Samia.

\section{Bahan}

Bahan yang digunakan pada penelitian ini yaitu 4 jenis kain tenun sutra Samia (kain A, B, C, dan D), malam batik, pewarna alam kulit kayu tingi (Ceriops tagal), TRO, tunjung, air keran, dan kapur.

\section{Peralatan}

Peralatan yang digunakan untuk penelitian ini yaitu pemanas, bejana tahan panas, bejana plastik atau sejenis, penyaring, neraca, batang pengaduk, gelas ukur, canting cap dari tembaga, meja cap, gunting, serta alat uji ketebalan kain (thickness gauge).

\section{Persiapan bahan}

Kain sutra Samia dipotong dengan ukuran 25 $\mathrm{cm} \times 25 \mathrm{~cm}$. Lalu diukur ketebalan tiap kain A, B, C, dan D. Sebelum diproses batik, kain contoh uji dibagi 2 perlakuan, sebagian tanpa perlakuan pendahuluan dan sebagian lainnya diberi perlakuan pendahuluan berupa penyemprotan air, agar lembab. Satu kg bahan pewarna alam tingi direbus dengan air $10 \mathrm{~L}$ sampai mendidih selama 2 jam. Bahan pewarna disaring sehingga didapatkan larutan warna alam. Bahan fiksasi dilarutkan dengan $1 \mathrm{~L}$ air dengan perbandingan masingmasing kapur $50 \mathrm{~g}$, tunjung $30 \mathrm{~g}$.

\section{Proses pembatikan}

Pembatikan dilakukan dengan teknik batik cap menggunakan canting cap motif kupu-kupu ukuran $16 \mathrm{~cm} \times 11 \mathrm{~cm}$ berbahan tembaga. Kain contoh uji diberikan perlakuan 1 kali dan 2 kali pencapan untuk melihat perbedaan daya tembus malam batik. Proses pembatikan menggunakan canting cap dapat dilihat pada Gambar 1. 


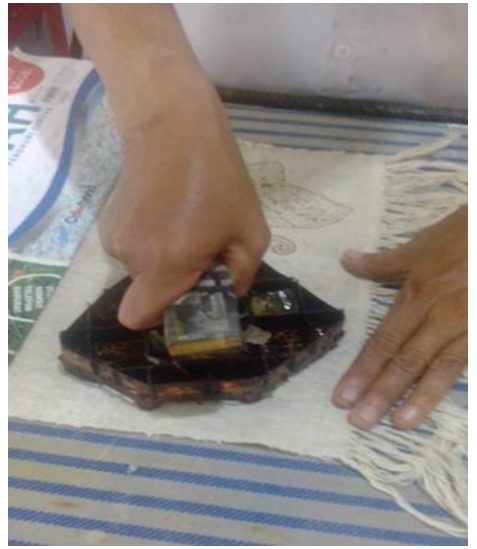

Gambar 1. Proses batik cap

\section{Pencelupan Batik}

Pencelupan dilakukan dalam keadaan dingin untuk masing-masing kain yang sudah dibatik cap dicelupkan ke dalam larutan zat warna alam tingi dengan teknik celup - keringkan sebanyak 5 kali pengulangan. Setelah itu kain difiksasi dengan cara dicelupkan ke dalam larutan fiksasi (kapur dan tunjung), kemudian dibilas dengan air sampai bersih dan dikeringkan.

\section{Pengumpulan Data}

Pengumpulan data secara kuantitatif dilakukan pada uji ketebalan sesuai SNI 08-02741999 Dimensi dan Berat Kain (Lebar Kain, Tebal Kain, Berat Kain). Sedangkan data kualitatif menggunakan skala Likert untuk mengukur persepsi terhadap suatu produk. Responden terdiri dari 5 peneliti, 5 penguji mutu barang, 5 instruktur, serta 5 perajin batik dengan total responden berjumlah 20 orang. Variabel yang dinilai berupa kesempurnaan motif, ketegasan tapak klowong dan tapak isen, daya tembus dan kerataan pelekatan malam batik pada kain sutra Samia.

Analisis data dilakukan menggunakan rumus sebagaimana Persamaan (1), (2), dan (3) berikut:

Skor $=T_{x} P$.

$\mathrm{T}$ : jumlah responden yang memilih

Pn : pilihan angka skor Likert

Interpretasi skor perhitungan

$\mathrm{X}=$ skor terendah Likert $\mathrm{x}$ jumlah responden

$\mathrm{Y}=$ skor tertinggi Likert $\mathrm{x}$ jumlah responden

Interval $(I)=100 /$ jumlah skor Likert

$$
\begin{aligned}
& =100 / 5 \\
& =20
\end{aligned}
$$

Index $\%=$ total skor/ Y x 100

Kriteria interpretasi skor berdasarkan interval

Angka 0\% - 20\% = tidak baik/buruk

Angka $21 \%$ - $40 \%$ = kurang baik
Angka $41 \%-60 \%$ = cukup baik

Angka $61 \%-80 \%$ = baik

Angka $81 \%$ - $100 \%$ = sangat baik

\section{HASIL DAN PEMBAHASAN Hasil Uji Ketebalan Kain}

Contoh uji kain tenun sutra Samia yang akan digunakan pada proses pembatikan dan pencelupan, terlebih dahulu dilakukan pengujian terhadap ketebalan kain. Hasil uji ketebalan kain sutra Samia dapat dilihat pada Tabel 1.

Tabel 1. Hasil uji ketebalan kain sutra Samia

\begin{tabular}{cc}
\hline Kode kain & $\begin{array}{c}\text { Tebal kain } \\
(\mathrm{mm})\end{array}$ \\
\hline A & 0,9541 \\
B & 1,1095 \\
C & 0,7261 \\
D & 1,0558 \\
\hline
\end{tabular}

Sumber : Laboratorium Pengujian Tekstil BBKB

\section{Hasil Pengamatan Daya Tembus Malam Batik}

Dari proses batik cap kain tenun sutra Samia pada variasi kondisi kering maupun lembab, dan juga jumlah proses pencapan malam batik (sebanyak 1 kali dan 2 kali), diperoleh hasil pengamatan terhadap daya tembus malam batik yang berbeda pada setiap kain. Daya tembus malam batik tersebut secara visual dapat dilihat pada Gambar 2.

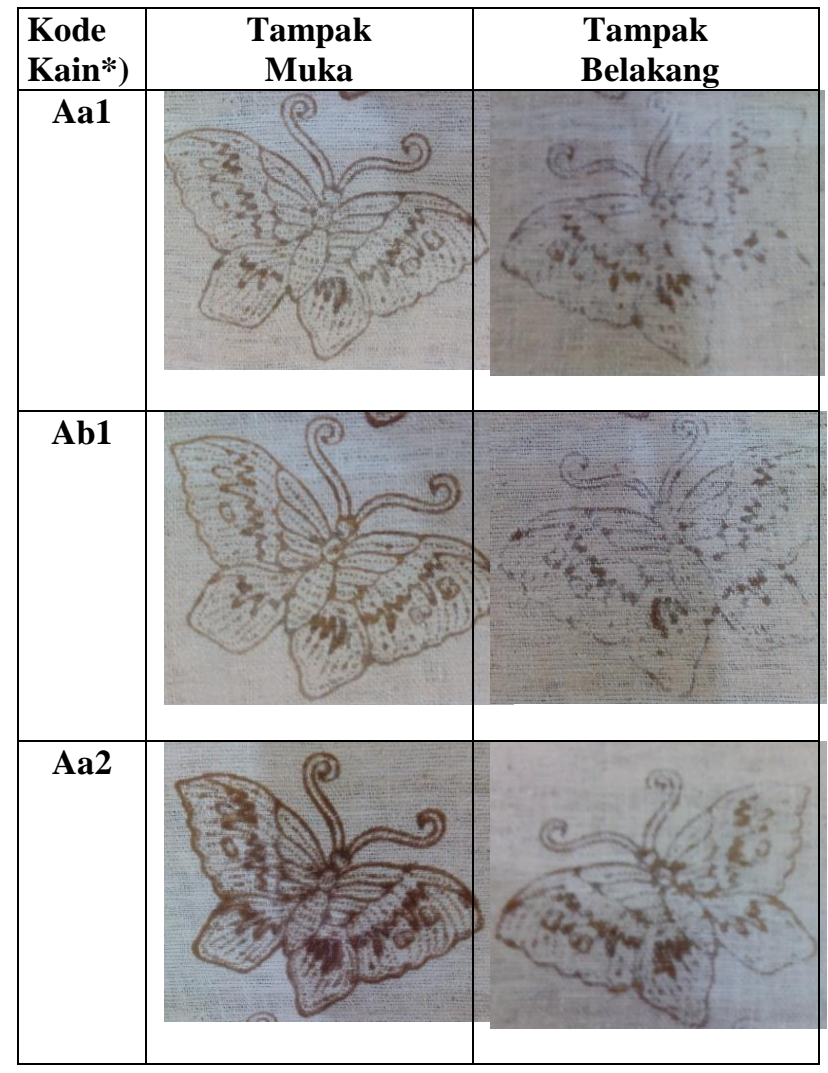




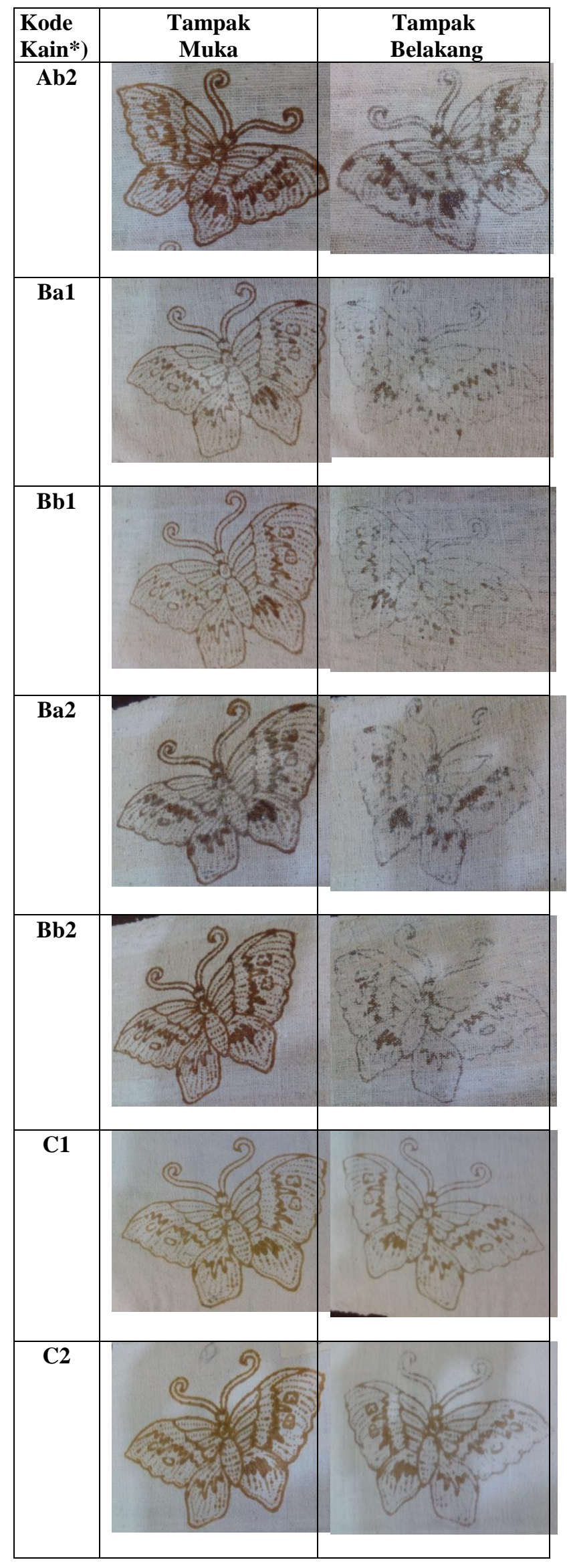

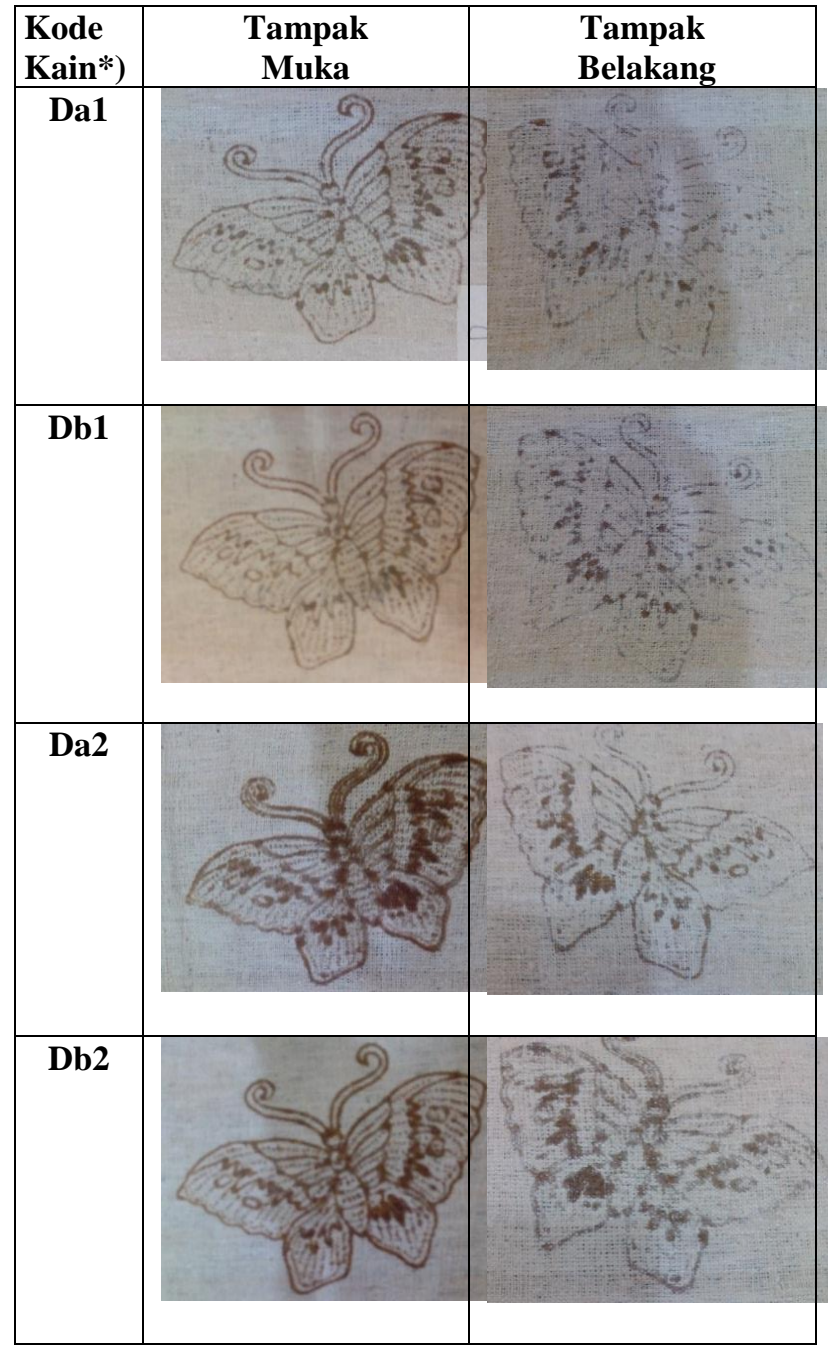

Gambar 2. Visualisasi daya tembus malam batik pada kain sutra Samia.

*) Keterangan Kode Kain Gambar 2:

Aa1 = kain A, kondisi kain kering (a), 1 kali proses pencapan malam batik

Ab1 = kain A, kondisi kain lembab (b), 1 kali proses pencapan malam batik

Aa2 = kain A, kondisi kain kering (a), 2 kali proses pencapan malam batik

Ab2 = kain A, kondisi kain lembab (b), 2 kali proses pencapan malam batik

Ba1 = kain B, kondisi kain kering (a), 1 kali proses pencapan malam batik

Bb1 = kain B, kondisi kain lembab (b), 1 kali proses pencapan malam batik

Ba2 = kain B, kondisi kain kering (a), 2 kali proses pencapan malam batik

Bb2 = kain B, kondisi kain lembab (b), 2 kali proses pencapan malam batik

Ca1 = kain C, kondisi kain kering (a), 1 kali proses pencapan malam batik

$\mathbf{C a} 2=$ kain $\mathrm{C}$, kondisi kain kering (a), 2 kali proses pencapan malam batik

Da1 = kain D, kondisi kain kering (a), 1 kali proses pencapan malam batik 
Db1 = kain D, kondisi kain lembab (b), 1 kali proses pencapan malam batik

Da2 $=$ kain D, kondisi kain kering (a), 2 kali proses pencapan malam batik

Db2 = kain D, kondisi kain lembab (b), 2 kali proses pencapan malam batik

\section{Hasil Pengamatan Motif Batik}

Hasil pengamatan secara visual terhadap motif batik yang dihasilkan pada berbagai variasi ketebalan kain, kondisi perlakuan awal kain, jumlah pencapan malam batik, dan jenis fiksasi, dapat dilihat pada Gambar 3.
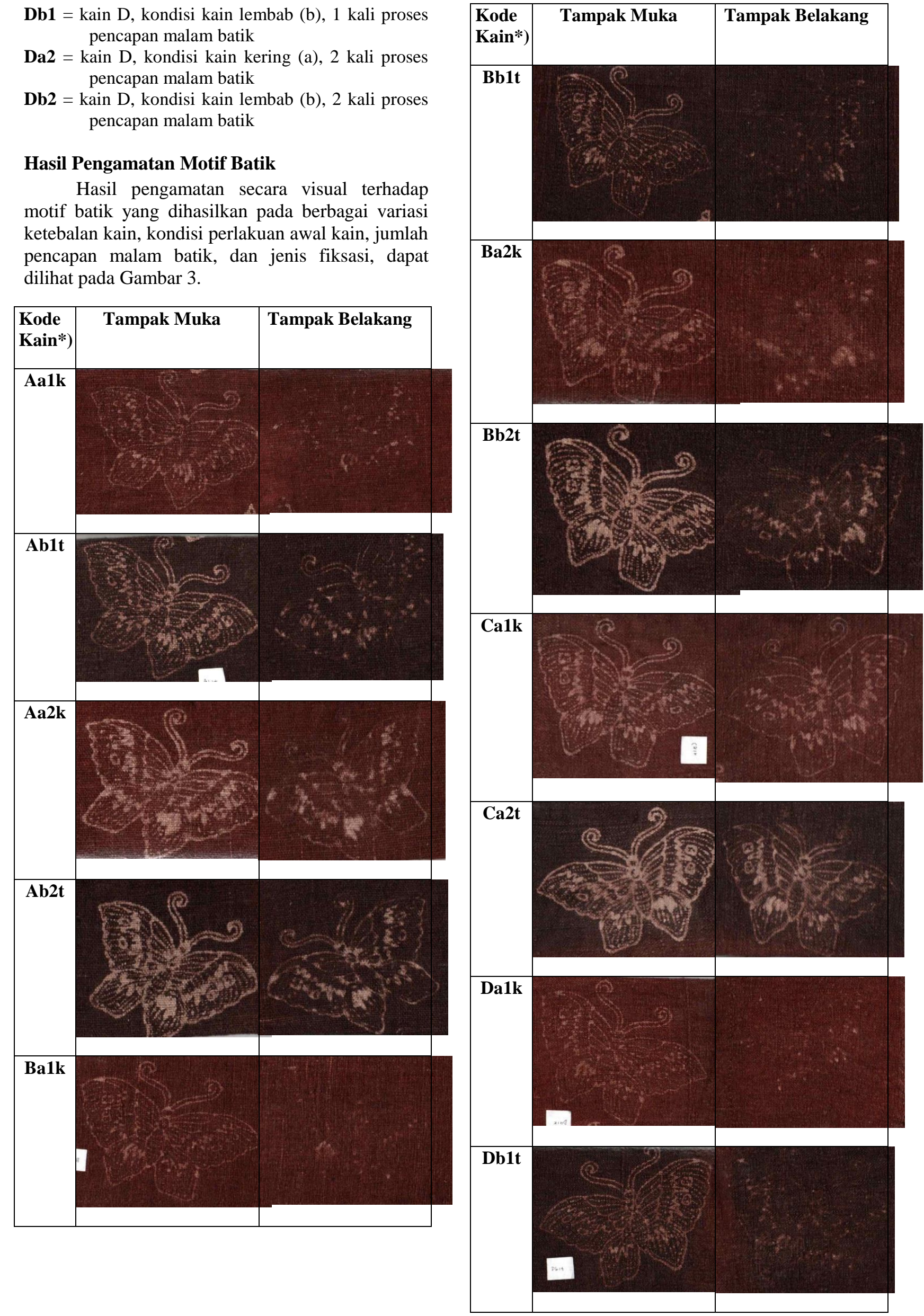


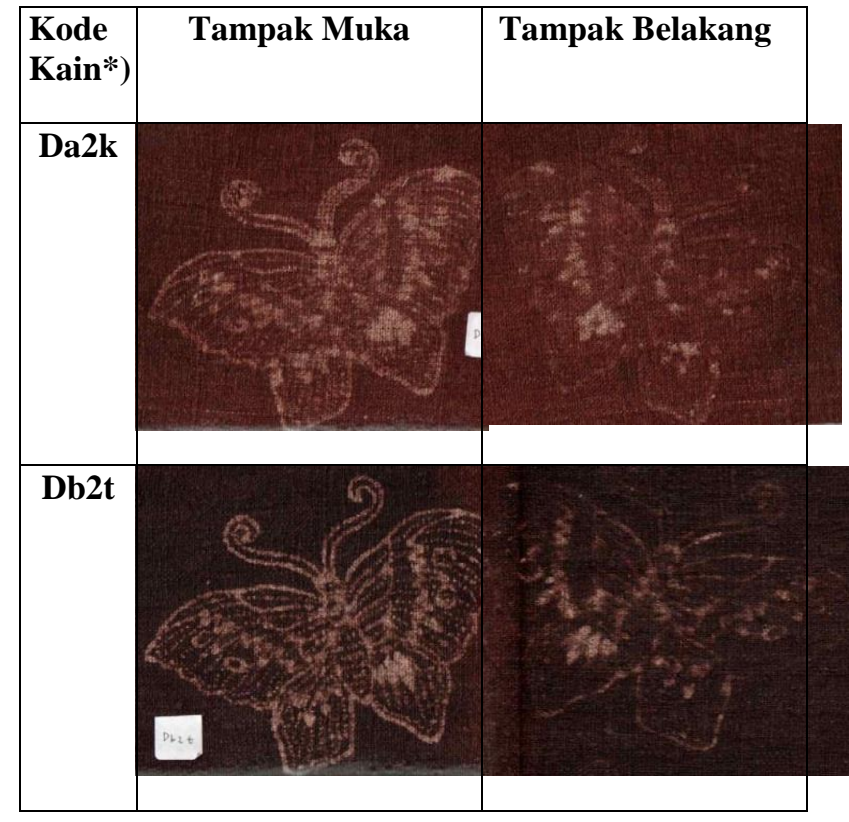

Gambar 3. Visualisasi hasil motif batik pada kain sutra Samia

Keterangan Kode Kain Gambar 3:

Aa1k = kain A, kondisi kain kering (a), 1 kali proses pencapan malam batik, fiksasi kapur $(\mathrm{k})$

Ab1t $=$ kain A, kondisi kain lembab (b), 1 kali proses pencapan malam batik, fiksasi tunjung $(\mathrm{t})$

Aa2k = kain A, kondisi kain kering (a), 2 kali proses pencapan malam batik, fiksasi kapur $(\mathrm{k})$

Ab2t $=$ kain A, kondisi kain lembab (b), 2 kali proses pencapan malam batik, fiksasi tunjung $(\mathrm{t})$

Ba1k = kain B, kondisi kain kering (a), 1 kali proses pencapan malam batik, fiksasi kapur $(\mathrm{k})$

Bb1t $=$ kain B, kondisi kain lembab (b), 1 kali proses pencapan malam batik, fiksasi tunjung $(\mathrm{t})$

Ba2k = kain B, kondisi kain kering (a), 2 kali proses pencapan malam batik, fiksasi kapur $(\mathrm{k})$

Bb2t $=$ kain B, kondisi kain lembab (b), 2 kali proses pencapan malam batik, fiksasi tunjung $(\mathrm{t})$

Ca1k = kain C, kondisi kain kering (a), 1 kali proses pencapan malam batik, fiksasi kapur $(\mathrm{k})$

Ca2t $=$ kain C, kondisi kain kering (a), 2 kali proses pencapan malam batik, fiksasi tunjung $(\mathrm{t})$

Da1k = kain D, kondisi kain kering (a), 1 kali proses pencapan malam batik, fiksasi kapur $(\mathrm{k})$

Db1t $=$ kain D, kondisi kain lembab (b), 1 kali proses pencapan malam batik, fiksasi tunjung $(\mathrm{t})$

Da2k = kain D, kondisi kain kering (a), 2 kali proses pencapan malam batik, fiksasi kapur $(\mathrm{k})$

Db2t $=$ kain D, kondisi kain lembab (b), 2 kali proses pencapan malam batik, fiksasi tunjung (t)

Nilai indeks (\%) hasil interpretasi motif pada kain sutra Samia dapat dilihat pada Tabel 2.
Tabel 2. Indeks interpretasi (\%) terhadap motif

\begin{tabular}{lccc}
\hline Kode & \multicolumn{3}{c}{ Motif } \\
\cline { 2 - 4 } Kain & $\begin{array}{c}\text { Kesempur- } \\
\text { naan motif }\end{array}$ & $\begin{array}{c}\text { Ketegasan } \\
\text { tapak } \\
\text { klowong }\end{array}$ & $\begin{array}{c}\text { Ketegasan } \\
\text { tapak isen }\end{array}$ \\
\hline Aa1k & 48 & 44 & 39 \\
Ab1t & 71 & 66 & 63 \\
Aa2k & 64 & 61 & 47 \\
Ab2t & $\mathbf{8 4 *}$ & 78 & 71 \\
Ba1k & 49 & 49 & 41 \\
Bb1t & 60 & 61 & 56 \\
Ba2k & 54 & 53 & 47 \\
Bb2t & 81 & $\mathbf{7 9 *}$ & $\mathbf{7 6} *$ \\
Ca1k & 61 & 58 & 52 \\
Ca2t & 79 & $\mathbf{7 9 *}$ & 74 \\
Da1k & 41 & 43 & 36 \\
Db1t & 63 & 60 & 57 \\
Da2k & 48 & 47 & 37 \\
Db2t & 74 & 69 & 62 \\
\hline ) & & &
\end{tabular}

*) nilai tertinggi

Nilai indeks (\%) hasil interpretasi daya tembus malam batik pada kain sutra Samia dapat dilihat pada Tabel 3 berikut.

Tabel 3. Indeks interpretasi (\%) terhadap malam batik

\begin{tabular}{ccc}
\hline \multirow{2}{*}{$\begin{array}{c}\text { Kode } \\
\text { Kain }\end{array}$} & \multicolumn{2}{c}{ Malam batik } \\
\cline { 2 - 3 } & Daya tembus & $\begin{array}{c}\text { Kerataan pelekatan } \\
\text { malam }\end{array}$ \\
\hline Aa1k & 29 & 41 \\
Ab1t & 39 & 56 \\
Aa2k & 44 & 58 \\
Ab2t & 59 & $\mathbf{7 0}$ \\
Ba1k & 27 & 42 \\
Bb1t & 32 & 45 \\
Ba2k & 29 & 42 \\
Bb2t & 41 & 67 \\
Ca1k & 53 & 54 \\
Ca2t & $\mathbf{6 0}$ & 66 \\
Da1k & 25 & 37 \\
Db1t & 32 & 43 \\
Da2k & 36 & 39 \\
Db2t & 50 & 59 \\
\hline
\end{tabular}

*) nilai tertinggi 


\section{Ketebalan Kain}

Menurut Cooke, ketebalan kain merupakan variabel yang paling penting dalam menentukan laju perpindahan panas dan mempengaruhi permeabilitas udara dan daya serap kelembaban. ${ }^{15}$ Dari Tabel 1, hasil uji ketebalan kain sutra Samia berkisar antara 0,7261 sampai $1,1095 \mathrm{~mm}$ dengan berturut-turut dari nilai paling rendah (paling tipis) sampai nilai paling tinggi (paling tebal) yaitu contoh uji $\mathrm{C}$, dengan nilai ketebalan $0,7261 \mathrm{~mm}$, contoh uji A $0,9541 \mathrm{~mm}$, contoh uji D $1,0558 \mathrm{~mm}$, dan terakhir contoh uji B $1,1095 \mathrm{~mm}$.

Ketebalan kain pada 4 kain sutra Samia berbeda-beda, hal ini disebabkan karena kokon sutra Samia tidak bisa dipintal berupa filamen melainkan spunsilk sehingga benang hasil pintalannya terdapat slub dan tidak rata. ${ }^{16} \mathrm{Di}$ samping itu juga benang sutra yang ditenun masih merupakan hasil pintal manual sehingga tingkat kerataannya tidak sama, bergantung juga pada tingkat kemahiran pemintal. Kerataan tebal kain yang dihasilkan juga akan tidak rata.

Semakin besar nomor benang pemintalan, maka semakin halus dan semakin kecil benang yang dihasilkannya. Kehalusan nomor benang ini yang berpengaruh pada hasil kain yang tipis. Sebaliknya, semakin kecil nomor benang, maka akan semakin besar dan kasar benang yang dihasilkan sehingga kain hasil tenunan menjadi lebih tebal. Ketebalan kain sangat erat hubungannya dengan jumlah diameter benang di lusi dan pakan. ${ }^{15}$

\section{Motif Batik}

Dari hasil interpretasi responden mengenai kesempurnaan motif batik yang dihasilkan pada ke4 kain sutra Samia, pada Tabel 2 didapatkan index $\%$ paling tinggi yaitu pada kode kain Ab2t (kain A dengan perlakuan kondisi kain lembab, 2 kali pencapan, dan fiksasi tunjung) dengan nilai 84 , masuk dalam kategori "Sangat Baik".

Untuk ketegasan tapak klowong nilai tertinggi diperoleh pada kode kain Bb2t (kain B, kondisi lembab, 2 kali pencapan, dan fiksasi tunjung) dan kode kain Ca2t (kain C, kondisi kering, 2 kali pencapan, dan fiksasi tunjung). Kedua contoh uji tersebut memiliki nilai 79 , artinya masuk dalam kategori "Baik". Sedangkan untuk ketegasan tapak isen, nilai tertinggi diperoleh pada kain $\mathrm{Bb} 2 \mathrm{t}$ (kain B, kondisi lembab, 2 kali pencapan, dan fiksasi tunjung) mempunyai nilai sebesar 76, masuk dalam kategori "Baik".

Menurut Singh dan Gahlot, ${ }^{17}$ suhu lilin cair juga mempengaruhi penampilan akhir dari desain batik. Pada suhu rendah, lilin tidak memadai untuk melekat dan menembus dengan benar pada kain dan pada suhu yang lebih tinggi lilin cenderung mulai mencair sehingga motif akan tidak tegas/blur.

Fiksasi tunjung ( $t$ ) menghasilkan warna yang lebih gelap, kontras dengan warna pada motif, klowong dan isen sehingga akan tampak lebih jelas/ tegas. Pada kain yang tebal, motif batik yang dihasilkan akan semakin tidak tegas, sedangkan semakin tipis suatu kain, maka semakin tegas motif batik yang dihasilkan.

\section{Malam Batik}

Dari Tabel 3, untuk daya tembus malam batik, nilai paling tinggi diperoleh pada kain $\mathrm{Ca} 2 \mathrm{t}$ (kain C, kondisi kering, 2 kali pencapan, dan fiksasi tunjung), dengan nilai 60, masuk dalam kategori "Cukup Baik". Jika merujuk pada Tabel 1, kain C memiliki nilai ketebalan kain paling rendah dibandingkan dengan kain $\mathrm{A}, \mathrm{B}$, dan $\mathrm{D}$, yaitu sebesar 0,7261 $\mathrm{mm}$, sehingga memungkinkan malam batik dapat menembus lebih baik, dibandingkan kain lainnya.

Menurut Haerudin dan Atika, kualitas lilin batik dipengaruhi oleh bahan baku malamnya, seperti gondorukem yang berfungsi membantu daya tembus malam batik pada kain. ${ }^{18}$ Proses pelekatan malam juga lebih baik pada proses 2 kali pencapan, dibandingkan proses pencapan yang hanya 1 kali. Sedangkan untuk kerataan pelekatan malam batik, nilai tertinggi diperoleh pada kain Ab2t (kain A, kondisi lembab, 2 kali pencapan, dan fiksasi tunjung), dengan nilai 70, masuk dalam kategori "Baik".

Pada Tabel 1, ketebalan kain A sebesar $0,9541 \mathrm{~mm}$, merupakan nilai terendah kedua setelah kain C. Tetapi nilai kerataan pelekatan malam batiknya lebih baik dari kain $\mathrm{C}$, hal ini dapat disebabkan karena adanya perlakuan sebelum pencapan. Kain A dilakukan penyemprotan air dengan spray terlebih dahulu, sehingga kondisi kain lembab, berbeda dengan kain $\mathrm{C}$ yang dilakukan pencapan dalam kondisi kering. Semakin tebal kain, maka akan semakin sulit untuk ditembus oleh malam batiknya. Dibutuhkan waktu yang lebih lama untuk malam batik meresap pada serat kain, pada ketebalan kain yang lebih tinggi. Di samping itu, malam batik akan lebih cepat membeku/dingin akibat panas berkurang karena terkena udara. Hal ini mengkonfirmasi pendapat Cruz, bahwa ketebalan kain mempengaruhi sifat penyerapan air. ${ }^{19}$

\section{KESIMPULAN}

Dari hasil penelitian dapat disimpulkan bahwa kain tenun sutra Samia dapat digunakan sebagai media batik. Ketebalan kain, kondisi perlakuan awal, proses pencapan, serta jenis fiksasi yang berbeda, akan berpengaruh pada kesempurnaan motif, ketegasan tapak klowong dan tapak isen, daya tembus, serta kerataan malam batik yang dihasilkan pada kain tenun sutra Samia. 


\section{SARAN}

Sebagai tindak lanjut, perlu dilakukan evaluasi terhadap nilai ketuaan warna (K/S) dan uji beda warna $\left(\mathrm{L}^{*}, \mathrm{a}^{*}, \mathrm{~b}^{*}\right)$ terhadap warna acuan yang dipilih, sehingga kesimpulan yang diperoleh akan lebih utuh.

\section{UCAPAN TERIMA KASIH}

Ucapan terima kasih kepada Ibu Titik Purwati Widowati selaku Kepala Balai Besar Kerajinan dan Batik yang telah mendanai kegiatan ini, Ibu Farida \& Bapak Isnaini selaku Kabid Saristand dan Kasie Saristik yang mendukung kegiatan ini serta Bapak Kamijana \& Ibu Eni Sudiarti yang terlibat dalam kegiatan ini.

\section{PUSTAKA}

1. Iskandar \& Kusyati, E. Batik Sebagai Identitas Kultural Bangsa Indonesia Di Era Globalisasi. Gema XXX/52, 2456-2472 (2017).

2. Kusumastuti, A. \& Syamwil, R. The Recycle of Batik Wax: an Effort towards Environmental Friendly Process. Int. J. Innov. Res. Adv. Eng. 3, 48-51 (2016).

3. SNI 0239:2014, Batik - Pengertian dan Istilah. 1-7 (2014).

4. Kudiya, K., Sumintono, B., Sabana, S. \& Sachari, A. Batik Artisans' Judgment of Batik Wax Quality and Its Criteria: An Application of the Many-Facets Rasch Model. in Pacific Rim Objective Measurement Symposium (PROMS) 2016 Conference Proceedings (ed. Zhang, Q.) 27-37 (springer, 2016).

5. Hakim, M. L. Batik Sebagai Warisan Budaya Bangsa \& Nation Brand Indonesia. J. Int. Stud. 1, No.1, 60-89 (2018).

6. Indonesian Batik. https://ich.unesco.org/en/search-00795?q=batik (2009).

7. Apriliana, S. S. \& Syamwil, R. Pengaruh Konstruksi Kain Terhadap Kualitas Batik Dengan Teknik Wet On Wet (WOW). Fash. Fash. Educ. J. FFEJ 3 (1), 1-6 (2014).

8. Types of Silk. https://inserco.org/en/statistics (2013).

9. Syabana, D. K., Ekarini, N. \& Satria, Y.
Pewarnaan Benang Sutra Samia Menggunakan Pewarna Batik Alami dan Mordan Akhir Tunjung, Tawas, dan Kapur Tohor. in Prosiding Seminar Nasional Tekstil 115-122 (Balai Besar Tekstil, 2019).

10. Lestari, D. W. \& Satria, Y. Pemanfaatan Kulit Kayu Angsana (Pterocarpus indicus) Sebagai Sumber Zat Warna Alam Pada Pewarnaan Kain Batik Sutra. Din. Kerajinan dan Batik 34, No.1, 35-42 (2017).

11. Murwati, E. S. Teknologi Proses Batik Kombinasi Sasirangan Pada Kain Foalisima, Primisima dan Sutra. Din. Kerajinan dan Batik 22, 28-38 (2005).

12. Effect of Yarn Twist On Fabric. https://textilecourse.blogspot.com/2018/03/effe ct-yarn-twists-fabric.html (2018).

13. Mandegani, G. B., Setiawan, J., Atika, V. \& Haerudin, A. PERSEPSI KUALITAS BATIK TULIS. Din. Kerajinan dan Batik 35, 75-84 (2018).

14. Syabana, D. K., Ekarini, N., Hardjanto, P. \& Sudiarti, E. EKSPLORASI BATIK PADA KAIN TENUN SUTRA Samia cynthia ricini UNTUK PRODUK FESYEN. (2019).

15. Cooke, B. The physical properties of weft knitted structures. in Advances in Knitting Technology 37-47 (woodhead, 2011). doi:10.1533/9780857090621.1.37.

16. Borah, M. P., Kalita, B. B. \& Phukan, A. R. Physio-mechanical properties of Eri silk and its union fabrics. Int. J. Chem. Stud. 7 (1), : 23982401 (2019).

17. Singh, A. \& Gahlot, M. Effect of wax ratio and wax temperature on silk batik printing. Indian Silk 40, 26-29 (2001).

18. Haerudin, A. \& Atika, V. KOMPOSISI LILIN BATIK (MALAM) BIRON UNTUK BATIK WARNA ALAM PADA KAIN KATUN DAN SUTRA. Din. Kerajinan dan Batik 35, 25-32 (2018).

19. Cruz, J. et al. Study of moisture absorption characteristics of cotton terry towel fabrics. in Procedia Engineering (2017). doi:10.1016/j.proeng.2017.07.055. 